\title{
Of Heartache and Head Injury: Reading Minds in Persuasion
}

\author{
Alan Richardson \\ English, Boston College
}

\begin{abstract}
The new intellectual climate inaugurated by the cognitive revolution can help elicit neglected contexts for literary historical study, to pose new questions for analysis and reopen old ones. The current challenge to social constructionist accounts of subjectivity, for example, can lead to a fundamentally new reading of Jane Austen's last novel, Persuasion (1818). Austen's was a period when a dominant constructionist psychology - associationism - vied with emergent brain-based, organicist, and nativist theories of mind. Austen pointedly contrasts a heroine seemingly formed by a history of erotic disappointment with an antiheroine, whose character is transformed instead by a severe blow to the head, at a time when brain injury featured centrally in debates on the materiality of mind. Moreover, the novel's innovative narrative style and approach to characterization take up and extend the embodied approach to subjectivity being worked out contemporaneously by Romantic poets and brain scientists alike.
\end{abstract}

How might the study of literary history change in the wake of the "cognitive revolution" (Gardner 1985)? A few literary scholars, most notably Mary Crane and F. Elizabeth Hart, have begun to explore the tensions between relatively stable patterns of cognition and linguistic categorization on the one hand and the specific cultural and ideological milieus within which they develop and gain expression on the other (Crane 1998; Hart 1998). Such work illustrates Mark Turner's contention (posed elsewhere in this issue) that cognitive theory can inspire a "more sophisticated" notion of human history by supplementing the prevailing emphasis on cultural

Poetics Today 23:1 (Spring 2002). Copyright @ 2002 by the Porter Institute for Poetics and Semiotics. 
history with an increased attention to the claims of phylogenetic and ontogenetic history. Even within the current parameters of literary historical studies, however, an awareness of recent developments in cognitive theory and neuroscience can significantly affect critical practice by shifting attention to previously unexamined issues, providing new terms for the critical lexicon, and reopening questions foreclosed or effectively abandoned by the reigning consensus.

The British Romantic period, to cite a particularly rich example, has long been viewed as dominated by an associationist account of mind, relied upon by writers as diverse as William Wordsworth and Jane Austen, and challenged primarily by the transcendental idealism best represented by S. T. Coleridge (Caldwell 1945). However, as cognitive psychology and neuroscience have returned figures like F. J. Gall, with his brain-based, modular account of mind, to a central place in the history of psychology, a new view of British Romanticism has become available, one that places it in relation to the contemporary development of many basic neuroscientific concepts in the work of Gall and other early brain scientists (Marshall 1980; Clarke and Jacyna 1987). The new interest in the brain and nervous system, mediated by prominent writers like the poet-physician-psychologist Erasmus Darwin, regularly reported in the leading reviews, and given wide cultural circulation by the phrenology movement and the materialist-vitalist controversy, provided a striking alternative to mechanistic, tabula rasa psychology exemplified by the associationism of David Hartley (Reed 1997). Even Coleridge's seemingly original emphasis on an active mind, creating the world it perceives, can be viewed as formed in reaction to (while incorporating key elements of) the pioneering brain science of the day (Richardson 1999). At the same time, poets and novelists made contributions of their own to an active and embodied conception of mind, emphasizing the emotive, unconscious, and intuitive aspects of mental life that have long been associated with literary Romanticism but that are equally salient for Romantic-era brain science as well.

Austen is often thought of as a novelist working primarily from the empiricist standpoint of an experientially constructed subject, and a succession of critics have paid due attention to the education, socialization, and enculturation of her heroines (for example, Devlin 1975; Poovey 1984; Johnson 1988; Handler and Segal 1990). In Persuasion (1818), her final complete novel, however, Austen turns to biological and innate aspects of mind and character in an unusually deft manner, in tune with and in some ways ahead of the brain science of the era. Moreover, Austen's famously innovative style for conveying the heroine's impressions in Persuasion speaks as much to a 
new appreciation of unconscious mental life and embodied cognition as to a new mode for representing the flux of conscious experience.

The shift within Romantic-era discourses on mind and character from environmental to biological approaches to psychological behavior and subject formation emerges most starkly, perhaps, in the changing views of William Godwin. In the 1790 os Godwin presents a rigorous and influential social constructivist account of mind, one obviously indebted to John Locke. The "actions and dispositions of mankind," he writes, are the "offspring of circumstances and events, and not of any original determination that they bring into the world"; "innate principles" and "original differences" of physiological "structure" have no role in shaping mind or character (Godwin 1976 [1793]: 97-98). Education in particular, and the effects of social and political life-institutions and ideologies - in general, become all important in shaping and imprinting the mind's initially "ductile and yielding substance" for good or ill (111-12). By 1831, however, in Thoughts on Man, His Nature, Productions, and Discoveries, Godwin (1831: 29-30) has become convinced that "human creatures are born into the world with various dispositions" most likely rooted in the "subtle network of the brain." Contrary to the claim of Claude-Adrien Helvétius (and by implication his own earlier view) that the human character "depends upon education only, in the largest sense of that word," Godwin (41) now maintains that innate "temper" significantly shapes psychological development. "He must have been a very inattentive observer of the indications of temper in an infant in the first months of his existence, who does not confess that there are various peculiarities in that respect which the child brings into the world with him" (32).

Godwin's new emphasis on individuality, human "peculiarities," and innate predispositions reflects the considerable influence of the new brainbased psychologies of the Romantic era, particularly Gall's "organology." A later essay in Thoughts is devoted to the "extraordinary vogue" for phrenology, dismissing its precise division of the mind into "twenty-seven compartments" but accepting some of its basic premises: that the "thinking principle" is located in the brain, the "great ligament which binds together" body and mind; that the sensory "nerves all lead up to the brain" and acts of volition initiate "in the brain itself"; and that the brain is modular, with "one structure of the brain better adapted" for a given discrete "intellectual purpose" than another (363-65). A third essay in the collection shows a new appreciation, also cognate with "organology" and other brain-based psychologies, for the pervasive role of unconscious cognition or what Godwin (159) quaintly terms "human vegetation." As biological approaches to 
physiology came to displace mechanistic ones, brain-based models of mind took notice, in Johann Gottfried von Herder's (1966 [180o]: 179) phrase, of the "innate, organical, genetic" aspects of mind. Herder, Pierre-JeanGeorge Cabanis, and Gall all depart from "tabula rasa" accounts of mental development to argue that innate mental characters are "transmitted from family to family" by means of a heritable neural "organization" shaping experience even while being modified by various experiences (Cabanis 1981 [1802-1805], 2:569; Gall 1835, 1:135, 185). Because, however, the brain is inseparable for these writers from the entire nervous system with its intimate links to the circulatory and respiratory systems, the new psychologies that relocated the mind in the brain also emphasized a dense and intricate network of links between mental events and the bodily economy as a whole.

The novel of the Romantic era made its own contribution to this profound discursive shift regarding character, individuality, and temperament. The radical or "Jacobin" novel of the 179os offers a fleshed out version of the Lockean constructionist approach, showing in vivid detail how, as Mary Hays (1974 [1796], 1: 4) writes in Memoirs of Emma Courtney, "We are all the creatures of education." In place of the anecdotal childhood episode or two revealing innate bias of character supplied by earlier eighteenthcentury novelists such as Henry Fielding, detailed accounts of childhood and early education became the norm. Novelists learned to elaborate basic fairy-tale plots to display the "advantages of education," contrasting the fortunes of one of three daughters (or cousins) in Cinderella fashion (as in Austen's Mansfield Park [1814]) or one of two sisters (or friends) in the tradition of the "kind and unkind" tale type (as in Austen's Sense and Sensibility [1811]). Needless to add, the heroine with the best education - the one who has most thoroughly internalized moral principles and developed habits of self-regulation - wins out (Richardson 1994: 185-202).

As the example of Susan Ferrier's Marriage (1818) shows, however, notions of innate bias, if they ever disappeared entirely, were returning to at least complicate fictional representations of character by the time of the materialist-vitalist controversy in the late 1810s. Anticipating the later use of twin studies to explore issues of nature and nurture, Ferrier invents twin sisters, Mary and Adelaide, raised in different families according to markedly different principles. Mary, the sister whose more careful education has produced a "well-regulated mind," ends up (predictably enough) rising from her Cinderella status to marry happily and well, while her vacuous twin Adelaide (like Maria in Mansfield Park) marries a wealthy "fool" before ruining her reputation with an adulterous elopement (Ferrier 1986 [1818]: 299, 475). Complicating an otherwise schematic plot, however, is the twins' cousin Emily, who is raised in the same fashion and environment as Ade- 
laide but whose native intelligence and generosity assert themselves in a "noble" though "wild" character, lacking Mary's exemplary self-control to be sure but also remarkably free of Adelaide's meretriciousness and shortsighted egotism (444). Within another decade, novelists begin to take innate biases of character explicitly into account, using them to balance or at least qualify environmental influences on development. As Mary Shelley $(1985$ [1826]: 47) puts it in The Last Man (1826), "We are born; we choose neither our parents, nor our station; we are educated by others, or by the world's circumstances, and this cultivation, mingling with our innate disposition, is the soil in which our desires, passions, and motives grow" (emphasis added). Whereas Shelley's Frankenstein (1818) might be seen as the extreme expression of a socially constructed mind, featuring a monstrous character who is “'made' not born" (Poovey 1984: 128), Shelley's later work anticipates the growing influence of phrenological and other physiological conceptions of mind on the nineteenth-century novel from Charlotte Brontë on (Oppenheim 1991; Shuttleworth 1996).

Austen's portrayal of character in relation to experience has been seen as thoroughly Lockean in spirit though unusually deft in execution (Devlin 1975). Her novels include some of the most inventive and subtle reworkings of traditional tale types to display the effects of contrasting upbringings and the habits of self-scrutiny and discipline they instill - or fail to instill, as Sir Thomas finds to his grief in contrasting Fanny to her favored but miseducated elder cousins at the end of Mansfield Park. In Persuasion, Austen again deploys a Cinderella plot to set off the virtues of an undervalued heroine, Anne Elliot, to the detriment of her spoiled siblings, the status-conscious, superficial Elizabeth and the plaintive, self-involved Mary. Austen varies this traditional plot by making Anne the middle rather than the youngest sister as well as by introducing still another folk character type, the "false heroine," in the person of Louisa Musgrove (Propp 1968: 6o). As in many a folktale, the false heroine in Persuasion functions to delay the eventual union of the true heroine with her "object" (Frederick Wentworth) by temporarily displacing Anne and claiming Frederick for herself. As in many a domestic novel, Anne and Louisa are contrasted in terms of the quality of their upbringing and the degree of their self-discipline. Louisa is more "fashionable" and adept at superficial "accomplishments," while Anne is "more elegant and cultivated," showing modesty and selfrestraint where Louisa appears willful and flirtatious, a combination that proves nearly fatal at the novel's crisis point (Austen 1965 [1818]: 67).

That crisis-Louisa's mistimed leap toward Frederick's arms and her headfirst fall onto the paving stones of a massive seawall - introduces a further and more surprising contrast, this time one without precedent. For 
while Anne's character has been shaped over her twenty-seven years of often painful experience, most notably her mother's death (when Anne is fourteen) and her youthful break with Frederick (five years later), Louisa's character is "altered," remarkably and apparently for life, by a single incident, a severe blow on the head (223). Once "happy, and merry" and rather giddy, Louisa is, as a consequence of head injury, "turned into a person of literary taste, and sentimental reflection," sedentary and neurasthenic. "The day at Lyme, the fall from the Cobb, might influence her health, her nerves, her courage, her character to the end of her life, as thoroughly as it appeared to have influenced her fate" $(67,178)$.

Critics of Persuasion have not known quite what to make of the connection Austen poses here between nerves and character, head trauma and mental alteration, and sometimes they have simply made fun of it. "True, she has fallen on her head," writes one, "but it had never been a good one, and the blow seems to have cleared it" (Lascelles 1939: 78). To read what another calls the "zany incident at Lyme" (Gross 1993: 195) as slapstick, however, fails to do justice to what has been aptly described as the "most sensational moment of physical violence in Austen's work" (Sokolsky 1994: 136). It also fails to bring out the truly remarkable implications of Louisa's character change. At the very least, the fall and its consequences serve, in John Wiltshire's (1992: 187) phrase, as a "graphic reminder that human beings are bodies as well as minds." In the context of Romantic-era speculation on the brain and nerves, however, it also suggests that the relation between bodies and minds is of more consequence, at least in Persuasion, than critics of Austen have wanted to acknowledge.

Wiltshire offers his account of the body's salience in Persuasion to counterbalance readings that, he feels, may have exaggerated its "historicist dimension" (196). But Austen's portrayal of an embodied mind-most remarkably in relation to Louisa's fall but in quieter ways throughout the novel- has an important historicist dimension of its own. Head injury, strange as it may seem in retrospect, was a politically loaded topic at the very time Austen was writing Persuasion, when to question the immateriality of mind could mean to question the philosophical underpinnings of orthodox religious belief (Reed 1997: 14). From David Hartley to William Lawrence, proponents of physiological accounts of mind cite the effects of "Blows upon the Head" among other reasons to locate the mind in the brain - a notion that was still considered unproven, materialistic, and potentially subversive in Austen's time (Hartley 1967 [1749], 1: 19). Concussions serve, along with visual illusions, somnambulism, and intoxication, as favorite examples of what might be called in retrospect the neuropathology of everyday life. Particularly loaded are instances in which, as Andrew Combe (1841 [1825]: 473) writes, 
the "temper and moral sentiments have . . been entirely changed, in consequence of certain injuries to the brain, while the intellect remained unimpaired," suggesting that not only cognition but character is physiologically based. Some of these instances are evocative of Louisa's transformation, including Hartley's claim that "concussions" have sometimes resulted in a "Melancholy" temperament (Hartley 1967 [1749], 1, 399), or Gall's (1835, 2: 119) "lady of fine talents" who falls, striking the "back part of her head against the mantel-piece," and comes to lose "all of her brilliant qualities" as a result.

The ideological threat that such accounts represented is clear from the response they generated in establishment journals, conservative and liberal alike. A few months before Austen began work on Persuasion (in August 1815), in fact, the Edinburgh Review devoted a long article to countering the implications of an essay on localized brain injury published the year before in Philosophical Transactions of the Royal Society of London. The author, Sir Everard Home, was not the ready object of ridicule presented by the phrenologists and most of their allies, whom reviewers could dismiss for the outlandishness of their science as well as for the materialism and "Frenchinspired" radicalism it implied (Lawrence 1990: 223). In contrast, Home could be seen as something of a medical icon: fellow of the Royal Society, sergeant-surgeon to the king, professor at the College of Surgeons, protégé and executor of the celebrated physiologist John Hunter, and baronet. In his "Observations on the Functions of the Brain" (1814) Home avoids "general deductions," instead cataloging all of the cases of brain injury he has encountered to help "procure accurate information respecting the functions that belong to individual portions of the human brain." Nevertheless, the implications of Home's attempt to connect "still more closely the pursuits of anatomy with those of philosophy" were hard to miss: an intimate relation (if not identity) between mind and brain, a physiological account of mental function, and a brain-based, modular conception of mental behavior distinctly related to Gall's organology if far more scientifically respectable (Home 1814: 469).

Rather than attack Home directly, the reviewer in the Edinburgh Review instead compiles an imposing list of counterexamples intended to prove that brain injury need not disrupt mental functioning and ultimately that mental life can go on in the entire absence of a brain. Some of the examples approach surrealism in the nonchalance with which they treat head wounds and other neural insults. "VESLINGIUS found the end of a stilletto in the brain of a woman, who had been wounded by it five years before, but who had complained of nothing in the mean while but occasional head-ach; and ... LACUTUS mentions a case, in which the half of a knife remained 
in the brain of a man for eight years, without his being at all incommoded" ("Review of Sir Everard Home" 1815: 443). Five pages of such examples are given not as evidence of neural plasticity, which Cabanis (1981 [1802-1805], 1: 140) discusses from a neuropsychological perspective in the Rapports, but rather to dismiss altogether any necessary connection between the mental act of "Sensation" and "particular" parts of the brain ("Review of Sir Everard Home" 1815: 445). The reviewer then goes on to produce examples in which "the whole brain has been destroyed without loss of sensibility," though as one might imagine these are not very satisfying (446). "We have found indeed, several instances of children born without a brain who lived for a short time; but the state of the sensibility in these, is not quite unequivocally ascertained" (447-48). Nevertheless, the essay concludes that, despite the cases evidenced by a "person of SIR EVERARD HOME'S reputation," there are "very strong grounds for believing, that the brain is not at all concerned in the changes which precede Sensation," and if not in sensation, then not, "mutatis mutandis," in the "phenomena of Thought and Volition" $(448,440)$.

Home's paper on brain function and the response in the Edinburgh Review are worth noting in this context not of course as possible "sources" for Persuasion. They are valuable, rather, for underscoring the tense coexistence in Austen's day of two diametrically opposed yet equally credible notions of mind-body relations, one unabashedly dualistic and in line with orthodox notions of the soul, the other aligning mental acts with discrete brain functions and open to a materialist interpretation. These rival conceptions seem initially to correspond, in an odd way, to the contrasting subjectivities of the rival heroines of Persuasion: one shaped by mental and emotional experience, able to transcend bodily discomfort, and exemplifying Frederick's ideal of a "strong mind"; the other "altered" by an injury to the brain and even before that deficient (again according to Frederick) "in a point no less essential than mind" (Austen 1965 [1818]: 87, 192). One is living with the pangs of a broken heart, the other with the lasting effects of a cracked head. Though the episode on the Cobb is not meant to elicit laughter, these rival systems for representing subjectivity do collide comically later in the novel. When Anne, overwhelmed with emotion, struggles to compose herself after reading a passionate letter from Frederick, Louisa's mother, apparently converted to a brain-based psychology, needs reassurance that "there had been no fall in the case; that Anne had not, at any time lately, slipped down, and got a blow on her head; that she was perfectly convinced of having had no fall" (241). But Anne's very confusion here and elsewhere in the novel suggests that the comic disparity in this passage between mind and brain, heart and head, is something of a red herring. For the characteriza- 
tion of Anne touches, in its own way, on the embodied notion of mind, the fragmentation of the subject, and the greater appreciation of unconscious mental life, all characteristic of the new Romantic psychologies.

Mrs. Musgrove's comic mistake, that is, reasserts the contrast between Anne and Louisa while also emphasizing that this is a moment when, as Wiltshire (1992: 195) puts it, Anne's "body takes over." Not that Anne becomes even remotely comatose at such times; rather, her periods of dislocation mark the collision of conscious awareness with unconscious thoughts and feelings and the intense physiological sensations that accompany them. Anne may be prized for her "rational" demeanor, yet she also proves highly susceptible to "inner agitation" from sources not always consciously present to Anne herself, registered instead in the body in ways that at times become so pressing as to overwhelm the conscious subject (177). "The absolute necessity of seeming like herself produced then an immediate struggle, but after a while she could do no more. She began not to understand a word they said" (Austen 1965 [1818]: 240-41). The "struggle" between rational control and passionate feeling, conscious volition and the physiological rush of intense inner emotions manifests not a split between mind and body but the impossibility of ever teasing them apart. The illusory unity of the conscious subject is punctured by the actions of an embodied mind that often finds unconscious action and expression more expedient, working in despite of the conscious subject if need be. "Mary talked, but [Anne] could not attend ... she began to reason with herself, and try to be feeling less. . . Alas! with all her reasonings, she found, that to retentive feelings eight years may be little more than nothing" (85).

Underlying such passages is a view of mind as sensibility, less reminiscent of Locke than of Herder (1966 [180o]: 100) - "Its vibrating fibres, its sympathizing nerves, need not the call of Reason: they run before her, they often disobediently and forcibly oppose her"-or of Darwin, Gall, or Cabanis. Austen grants the "inward" senses (never discussed by Locke) the central role given them by brain-based Romantic psychologies, necessarily broaching the subject's fragmentation in the process. "For a few minutes she saw nothing before her. It was all confusion. She was lost; and when she had scolded back her senses, she found the others still waiting for the carriage" (Austen 1965 [1818]: 185). The intimation of a divided subject ("scolded back her senses") builds to the acknowledgment of a fundamental split between a superintending conscious self and a potentially unruly, desiring, unconscious other: "Why was she to suspect herself of another motive? . . One half of her should not always be so much wiser than the other half" (ibid.). In related passages, equally in keeping with the emphasis on unconscious mental life found throughout Romantic brain science, Anne performs com- 
plex behaviors in an explicitly "unconscious" manner, playing at the keyboard (a prominent example of nonconscious cognition in Darwin's Z00nomia 1794-1796, 1: 190-94) and even conversing "unconsciously" (Austen 1965 [1818]: 96, 113). Anne can make music and make conversational sense equally well without the benefit of conscious awareness, though her unconscious life emerges more spectacularly in those moments when she seems, for a time, altogether senseless.

Anne's periods of "confusion," episodes lasting up to "several minutes" when internal sensations crowd out external ones, rendering her unseeing and inattentive, bear an uncanny resemblance (seen from the outside) to Louisa's deeper passage into unconsciousness after her fall. Louisa's head injury calls attention, in sensationalistic fashion, to the mind's embodiment, a condition that is shown in more subtle ways to be shared by the characters around her. The chapter that recounts the accident is generally seen as the novel's dramatic hinge, limning the contrast between the two rivals by juxtaposing Louisa's "heedlessness" with Anne's display of the "resolution of a collected mind" (244). Yet the scene at the Cobb also softens that very contrast as one character after another succumbs to emotional and cognitive overload, lapsing into various mental states that appear not so very different from Louisa's. Frederick looks at the "corpse-like figure" of Louisa "with a face as pallid as her own"; Charles is rendered "immoveable"; Henrietta, "sinking under the conviction, lost her senses too, and would have fallen on the steps" (129-30). Overcome with genuine shock and horror, one character after another becomes, like Louisa, a prone or otherwise inert body.

Austen underscores the parallel in various ways as the episode continues to unfold. When Anne proposes to send Benwick for a doctor, "Every one capable of thinking felt the advantage of the idea," a formula that groups the fainting Henrietta and the "hysterical" Mary with the unconscious Louisa. Harville's arrival is described in terms that in context seem to reduce him to a physiological specimen: "Shocked as Captain Harville was, he brought senses and nerves that could be instantly useful" (130-31). Even the "thinking" characters, that is, are portrayed as organic assemblages of nerves and senses under duress. Frederick, though remaining sentient, becomes automaton-like, responding as mechanically as any Hartleyan association network when Anne mentions a surgeon. "He caught the word; it seemed to rouse him at once, and saying only, 'True, true, a surgeon this instant,", he begins rushing away when Anne reminds him that only Benwick "knows where a surgeon is to be found" (130). Even Anne, foremost among the minority who remain "rational," rises to the occasion through the "strength and zeal, and thought, which instinct supplied" (ibid.). Appearing just at 
this point in the episode, Austen's choice of "instinct" does not seem casual. At a time when writers like Coleridge adamantly distinguished between the "instinct" of beasts and the "higher" intuitions of human beings, countering "materialists" like Darwin, who view instinctive human responses as a crucial animal inheritance and a key manifestation of the adaptive "inner" senses, "instinct" was a loaded term, one that early brain scientists like Cabanis and Gall had only recently reasserted in the teeth of Locke's dismissal (Coleridge 1995, 2:1390). In this context Anne's most heroically "rational" episode could be placed on a continuum with, rather than directly opposed to, her automatic, nonrational, but quite natural responses elsewhere in the novel at times of heightened emotion. Marked by a "strong sensibility" from her adolescence, Anne is represented not as some eviscerated or denervated rational agent but as an emotive, embodied subject, uncommonly reasonable and also uncommonly sensitive (Austen 1965 [1818]: 165).

Anne's blend of exemplary rationality and heightened sensibility, her susceptibility to surges of emotion with their marked cognitive and physiological effects, and the mental splitting or fragmenting she regularly manifests together find voice in the stylistic innovation critics have noted in Persuasion. A. Walton Litz (1975: 228-29) first called attention to Austen's "move away from the Johnsonian norm" in the sentence structure of her last novel, with its "rapid and nervous syntax designed to imitate the bombardment of impressions upon the mind." Marilyn Butler (1987: 277) similarly describes Austen's "experiment with a new kind of subjective writing," marked by a "high-wrought nervous tension" in conveying a particular consciousness (Anne's), for which "the senses have a distinct advantage over reason and fact." It is appropriate that both critics use the term "nervous" to evoke the quality of Anne's subjectivity and the prose that conveys it, for in this novel mind cannot be disentangled from the central nervous system that enacts it. Austen's new subjective style is all the more innovative for prominently including the gaps and disruptions in the represented flux of consciousness, what Wiltshire (1992: 177) calls "invasions of feeling." Unconscious mental events are shown in a complex and frequently adversarial relation with conscious ones, and feeling is often known through its mark on the body before it can be registered in conscious awareness. "No, it was not regret which made Anne's heart beat in spite of itself, and brought the color into her cheeks when she thought of Captain Wentworth unshackled and free. She had some feelings which she was ashamed to investigate" (Austen 1965 [1818]: 178). Anne's shame here reminds us that the domestic novel, considered as an extension of the literature of female conduct, implicitly enjoins such inner splitting by insisting that "proper" young women feel desire for 
their future husbands - marry for love-without acknowledging such desire too soon, even to themselves (Richardson 1994: 191-92). Yet the deft interplay in passages like this between thought and feeling, physiological expression and conscious introspection signals not just another elaboration on the modest blush but a new, Romantic sense of mind-body relations.

Terms like "flow of consciousness" (Butler 1987: 290) or "interior monologue" (Litz 1975: 228) cannot entirely do this new style justice. Even if they allow for some shading from unconscious impulses or bodily intrusions upon introspective awareness, they tend to evoke a conscious, integral Cartesian subject, the central self that oversees the conscious flow or articulates the internal monologue. As represented through the "nervous" sentences of Persuasion, however, subjectivity seems corporate rather than monologic, unconscious feelings and ideas become as important as conscious ones, and the division between interior and exterior is regularly breached. Anne's "shudder," for example, should be read as a simultaneously physical and psychological reaction in the passage that describes Anne's semiconscious acknowledgment of her temporary interest in her wealthy cousin William Walter Elliot. "Anne could just acknowledge within herself such a possibility of having been induced to marry him, as made her shudder at the idea of the misery which must have followed" (Austen 1965 [1818]: 216). The tentative, dim character of Anne's acknowledgment ("just ... such a possibility") suggests that the psychic region "within herself" remains only flittingly and uncertainly available to conscious awareness. The "shudder" represents both an aversive reaction to the disturbing "idea" - one that seems to have emerged full-blown into Anne's conscious mind-as well as an important physiological cue that conveys not only to the reader but to Anne herself the emotional intensity of that reaction and the unforeseen danger it forestalls, not a moment too soon. The plot owes much of its tension, in fact, to the ongoing threat that feelings which can be read only haphazardly, through momentary glimpses, or indirectly, through their bodily manifestations, can always be misread. Frederick will continue to overvalue his feelings for Louisa, Anne will be "induced" to display feelings for Mr. Elliot, neither Frederick nor Anne will correctly gauge the strength or validity of their renewed feelings for one another. Frederick makes this dilemma explicit in an acknowledgment of his own: "Thus much indeed he was obliged to acknowledge - that he had been constant unconsciously, nay, unintentionally; that he had meant to forget her, and believed it to be done" (244). In a novel of the 1790's generation, the claim to have been constant "unintentionally" would be transparently absurd, the statement of a cad, the sort of thing that Darnford, in Mary Wollstonecraft's Maria (1798), might be expected to come up with. In Persuasion, however, the 
claim, self-serving as it obviously is, can nevertheless be considered sincere. Unconscious motives can contradict and even come to outweigh conscious ones, feelings that are "believed" to be forgotten can have been present, in retrospect, all along. It is a Romantic novel indeed, one that takes up and extends, in its innovatory syntax, characterization, and narrative style, the embodied approach to human subjectivity being worked out concurrently by Romantic poets like Coleridge and Keats and Romantic brain scientists like Gall and Bell.

The concurrence between Austen's late style and emergent biological notions of the subject would not commit her necessarily of course to viewing character or temperament as even partly shaped by heredity. Even if one believes that a significant change in brain physiology (such as the neurological effects of a particularly severe head injury) could bring about a change in temperament, one need not agree with Gall or Cabanis that certain patterns of neurophysiological organization associated with specific temperaments or character traits can be passed down within families like a snub nose or a predisposition to hemophilia. Physiological psychology and a renewed interest in the hereditary transmission of character traits, however, do generally go together in Romantic-era brain science, and it is significant that, in Persuasion, Austen seems to pose a similar connection. Again, the most overt example in the book concerns a relatively minor female character who functions as yet another foil to Anne, her former school friend Mrs. Smith. Smith's experience has been much harsher still than Anne's: marriage to a spendthrift husband, early widowhood, relative poverty ("unable even to afford herself the comfort of a servant"), and illness (165). Yet as Anne wonderingly observes: "In spite of all this ... she had moments only of langour and depression, to hours of occupation and enjoyment. How could it be?" (167). How could temperament so thoroughly belie the effects of experience? Mrs. Smith exemplifies, Anne decides, that "elasticity of mind, that disposition to be comforted, that power of turning readily from evil to good, and of finding employment which carried her out of herself, which was from Nature alone" (ibid.). Here at least is one character not altogether shaped by experience but with a pronounced (and one could add adaptive) native "disposition."

Anne herself initially seems another case altogether. Psychoanalytical critics of Persuasion argue that Anne's particular temperament is precisely what one would expect of a girl effectively abandoned by her mother at fourteen, a traumatic and formative experience that makes a history of heartbreak and melancholy seem to follow as a matter of course (Dalton 1995: 51). As Anita Sokolsky (1994: 133) writes, “Anne's tendency to melancholy emerges in reaction to the death of a mother whose attachment to her home 
and daughters had, terribly, made it 'no small matter of indifference to her to leave this life.' "Austen, however, does suggest that Anne's temperament may owe as much to a biological as to a psychological relation to the mother. Later in the same chapter in which Anne speculates on Mrs. Smith's elastic "disposition" (a key term for Gall and his sympathizers), Lady Russell remarks that Anne is "her mother's self in countenance and disposition"that she has inherited her mother's temperament along with her physical features (Austen 1965 [1818]: 172). Lady Russell's judgment is evidently one of long standing: in the novel's first chapter, her early preference for Anne reflects her sense that "it was only in Anne that she could fancy the mother to revive again" (37). A paragraph above, Sir Walter's contrary preference for his eldest daughter, Elizabeth, is similarly explained on the basis of physical and temperamental resemblance to a parent: "being very handsome, and very like himself, her influence had always been great" (ibid.). Few readers would disagree with Sir Walter's assessment; throughout the novel Elizabeth reacts and behaves in a manner all too like her father's. Physiology may not be destiny in Persuasion, but it seems to play no small role in character formation.

The links implied here between character and physique, heredity and fate, raise the issue of how sexual differences are perceived to shape differences in mind, an issue Austen raises herself toward the end of the book (237). In a novel that in various ways works to "upset conventional conjunctions of ideas about gender," it might seem that appeals to physiological notions of mind and hereditary notions of "disposition" could only serve to reassert those same conjunctions (Johnson 1988: 151-52). Both Sally Shuttleworth and Janet Oppenheim have demonstrated how in the Victorian era the new biological psychologies were invoked to "bear witness against women's brains" and to reassert conventional oppositions between male self-control and female helplessness, male rationality and female sensibility (Oppenheim 1991: 185). As John Elliotson, a radical materialist and early proponent of phrenology, puts it in Human Physiology (1835), the "male is formed for corporeal and intellectual power; the female for gentleness, affections, and delicacy of feeling" (quoted in Shuttleworth 1996: 82). These tendencies, though much exaggerated over the course of the nineteenth century, are certainly present already in the work of pioneers like Cabanis and Gall. Cabanis (1981 [1802-1805], 1: 183, 227) holds that women have "softer" brains than men and remain in some respects "children all their lives." Gall $(1835,3: 272)$ illustrates the power of instinct by observing that the "little girl reaches out her hand for the doll, as the boy, for a drum or sword." "The whole physical constitution of woman," he continues, "combines with her moral and intellectual character, to prove that she is destined, 
more particularly than man, to take care of children" (ibid.). For William Lawrence (1822: 94) the mind is "male or female, according to the sex of the body."

Yet as readily as the new physiological psychologies lent themselves to supporting the received dichotomies of the gender system, they could also serve to unsettle those same oppositions and, at least in principle, destabilize the traditional system of evaluations. William Hazlitt (1930-1934 [1829]), in a critique of phrenology, complains that Gall's organology weakens the distinction between men and women by localizing it, limiting it to relative differences between only several among the numerous brain "organs." "Women in general," Hazlitt (1930-1934 [1829], 20: 253) counters, "have more softness and flexibility both of mind and body than men - they have not the same strength and perseverance, but they take their revenge in tact and delicacy: Shall we suppose this marked and universal difference which runs through the whole frame and through every thought and action of life, to proceed from a particular bump or excrescence of the skull, and not to be inherent in the principle (whatever that may be) which feels, and thinks, at all times, and in all circumstances?" By fragmenting the mind and disrupting the continuity of the thinking "principle," the new physiological psychologies not only threaten orthodox notions of the soul but throw the system of absolute gender differences into question. If gender-specific mental differences can be localized, moreover, those local differences can be further eroded by the effects of accident and experience. Men, for example, come equipped with the same mental predisposition (and accompanying brain organ) for child-rearing as women but in a much less pronounced manner; through exercise, however, that organ can be developed and the original difference can be "repressed" (Gall 1835, 3:263, 275). A thoroughly "domestic" man like Captain Harville would fit readily into Gall's system but would seem aberrant within Hazlitt's (Austen 1965 [1818]: 120). The propensity for sexual behavior on the other hand is generally stronger in men but by no means always. For Gall, despite his commitment to pervasive gender differences, there are no absolute or unalterable distinctions.

In terms of their larger implications, the emergent brain-based psychologies of the era threatened to destabilize received notions of gender in more pervasive ways. Discussing the ambivalent relation of women writers to scientific discourse in the Romantic era, Marina Benjamin (1991: 27-28) remarks on the "masculine character of scientific epistemologies" that align the opposition of masculine to feminine with "dichotomies like rational/ emotional, deductive/intuitive, objective/subjective." But the biological psychologies of Darwin, Cabanis, and Gall were engaged in undoing those 
very dichotomies at a time when, according to Benjamin (28), the "cognitive role of the passions, imagination, sensation, and individual experience" was being fundamentally rethought. In giving an expanded and often leading role to unconscious cognition, instinctive behaviors, "inward" sensations, emotional reactions, and bodily sensation within mental life, Romantic brain science threw traditional valuations of reason over passion and mind over body into crisis. Moreover, although women still were seen as more emotional and "softer" than men, men were nevertheless fully implicated within a changing vision of the human, one that displaced the rational, disembodied, male-coded ideal subject with an embodied model of human subjectivity, forcing a revaluation of traditionally feminine prerogatives like sensibility and intuition.

Here too one finds unexpected convergence between Austen's experiments with representing character and subjective life in Persuasion and the physiological psychologies of her time. Another of the features supporting a "Romantic" reading of the novel is its revaluation of rationality and emotion, one that cuts across gender lines (Litz 1975: 227). The heroine after all is one who famously "had been forced into prudence in her youth" and "learned romance as she grew older," while Frederick too must learn to respect the wisdom of his "unconscious" and even "involuntary" feelings by the novel's close (Austen 1965 [1818]: 58). The novel's most systematically "rational" characters, Lady Russell and William Walter Elliot, are the very ones who cause the most pain and give the worst counsel $(42,173)$. Frederick's great advantage over Mr. Elliot in fact resides in his characteristic "ardour," a trait that is at once psychological and physical, described elsewhere as "glowing" $\left(5^{8}, 86\right)$. All of the sympathetic naval characters share this quality of "warmth," one singularly lacking in Frederick's rival (120). "Mr Elliot was rational, discreet, polished,- - but he was not open. There was never any burst of feeling, any warmth of indignation or delight" (173). Or, in Mrs. Smith's harsher terms, Elliot is a "cold-blooded being," a "man without heart" (206). This last phrase relies on the most conventional of figures, but in a novel that so insistently reevaluates the claims of the body, metaphors like heart ask to be taken quite seriously. In conjunction with terms like warmth and ardour, heart functions metaphorically precisely at the uncertain borders between psyche and soma, where character traits are indistinguishable from the "glowing" physical sensations that make them known - to the self as well as to others. (The very notion of temperament, a term obviously allied to temperature, ultimately relies on the same basic metaphorical pattern [Kagan 1994: 34-35; Sweetser 1990: 28]). Harville is "warm-hearted" not just metaphorically but in the concrete way he experiences his own body and thus knows his own mind; after expressing 
his love for his wife and children "in a tone of strong feeling," he adds, "I speak, you know, only of such men as have hearts!' pressing his own with emotion" (Austen 1965 [1818]: 119, 238). Men who fail to speak from feeling and to feel from the body are not to be trusted in Persuasion.

Not that feelings, sensations, vocal tones, and physiological displays can be trusted in any simple way either. Austen's turn to an embodied epistemology in Persuasion introduces new complications of its own, such as the difficulties both Anne and Frederick encounter first in consciously perceiving, then in fully acknowledging, their "unconscious" desire for one another. Sensations can be misinterpreted and feelings under- or overvalued, as in the case of Benwick, whose broken heart heals sooner than anyone, least of all himself, could reasonably suppose. Mrs. Musgrove, who rekindles feelings for a son's death that she seems not really to have felt at the time, and whose "substantial" physical bulk is said to belie her feelings of "tenderness," functions as an icon of such misprision (Austen 1965 [1818]: 92). This is still a Jane Austen novel. It is, however, a Jane Austen novel like no other, and its difference owes a great deal to its affinities with the biological psychologies just then becoming notorious through the debates on phrenology and the materialist-vitalist controversy. Although it has been claimed that Austen "all but erases" the body in her novels and that a body reconstructed from her lexicon would have no thighs, no "intestines, wombs, or navels," not even fingers or toes (Shields 1991: 132), the body is crucial to character, plot, and subjective life in Persuasion. The skin that glows or goes pallid, the heart that swells or goes "cold," the "susceptible" nerves and the brain that, once injured, must be "set to rights" all speak of a mind that has no location or meaning apart from the body (Austen 1965 [1818]: 144, 181).

It could be objected that this new view of Persuasion, relying as it does primarily on Romantic-era documents, could have been produced without the inspiration of recent neuroscience and cognitive theory, which collectively have done so much to revive interest in the embodiment, modularity, and nonconscious aspects of mind. Perhaps, in principle, a literary scholar could have interpreted and contextualized Persuasion somewhat along the lines above without such inspiration, but in practice Austen's evident interest in questions of mind-body interaction and their fictional representation has been almost entirely overlooked. For most literary historians and critics of the period, however elaborate their attention to the mind, the brain may as well not have existed - not just Romantic-era work on and debates about the brain but the brain itself. One recent psychoanalytic reader of Persuasion, for example, remarks (of Louisa's fall) that "Louisa's 'lifeless'-ness is, of course, only a concussion - 'there was no injury but to the head' - suggesting that the significance of the episode is mainly psychological: everything 
has taken place in the head" (Dalton 1995: 54). Novelists, of course, are entirely at liberty to construct characters who, like this version of Louisa, do not have brains and therefore cannot suffer neurological injury. But as should be clear by now, that is by no means how Austen chose to construct the characters of Persuasion. Even a reader like Wiltshire (1992: 4, 165), however, with a focus on the body, tends to emphasize "psychological" phenomena like "hypochondria" and "hysteria" in his reading of Austen and, though very perceptive regarding the contrast between Louisa's "physical" and Anne's "mental" pain, fails to note how thoroughly this dichotomy breaks down in the novel. We have hardly begun to understand how pervasively and centrally the literature of the Romantic era is caught up in emergent notions of an embodied mind because we have ourselves, up to now, shown almost no interest in the brain or in the remarkable developments in brain science of our own era.

\section{References}

Austen, Jane 1965 [1818] Persuasion, edited by D. W. Harding (London: Penguin).

Benjamin, Marina 1991 "Elbow Room: Women Writers on Science, 1790-1840," in Science and Sensibility: Gender and Scientific Inquiry, edited by Marina Benjamin, 27-59 (Oxford: Blackwell).

Butler, Marilyn 1987 Jane Austen and the War of Ideas (New York: Oxford University Press).

Cabanis, Pierre-Jean-George 1981 [1802-1805] On the Relations between the Physical and Moral Aspects of Man, edited by George Mora, translated by Margaret Duggan Saidi, 2 vols. (Baltimore, MD: Johns Hopkins University Press).

Caldwell, James Ralston

1945 Fohn Keats' Fancy: The Effect on Keats of the Psychology of His Day (Ithaca, NY: Cornell University Press).

Clarke, Edwin, and L. S. Jacyna

1987 Nineteenth-Century Origins of Neuroscientific Concepts (Berkeley: University of California Press).

Coleridge, S. T.

1995 Shorter Works and Fragments, edited by H. J. Jackson and J. R. de J. Jackson, 2 vols. (London and Princeton, NJ: Routledge and Princeton University Press).

Combe, Andrew

1841 [1825] "On the Effects of Injuries of the Brain upon the Manifestations of the Mind," in A System of Phrenology, edited by George Combe, 46o-73 (New York: Colyer). First published in Transactions of the Phrenological Society 1: 183-208.

Crane, Mary Thomas

1998 "Male Pregnancy and Cognitive Permeability in Measure for Measure," Shakespeare Quarterly 49(3): 269-92.

Dalton, Elizabeth

1995 "Mourning and Melancholia in Persuasion," Partisan Review 62(1): 49-59.

Darwin, Erasmus

1794-1796 Zoonomia; or, The Lawes of Organic Life, 2 vols. (London: J. Johnson). 
Devlin, D. D.

1975 Fane Austen and Education (London: Macmillan).

Ferrier, Susan

1986 [1818] Marriage, edited by Rosemary Ashton (Harmondsworth, U.K.: Penguin).

Gall, François Joseph

1835 On the Functions of the Brain and of Each of Its Parts: With Observations on the Possibility of Determining the Instincts, Propensities, and Talents, or the Moral and Intellectual Dispositions of Men and Animals by the Configuration of the Brain and Head, translated by Winslow Lewis, 6 vols. (Boston: Marsh, Capen, and Lyon).

Gardner, Howard

1985 The Mind's New Science: A History of the Cognitive Revolution (New York: Basic Books).

Godwin, William

1831 Thoughts on Man, His Nature, Productions, and Discoveries (London: Effingham Wilson).

1976 [1793] Enquiry concerning Political Justice and Its Influence on Modern Morals and Happiness, edited by Isaac Kramnick (Harmondsworth, U.K.: Penguin).

Gross, Gloria Sybil

1993 "Flights into Illness: Some Characters in Jane Austen," in Literature and Medicine during the Eighteenth Century, edited by Marie Mulvey Roberts and Roy Porter, 188-99 (London: Routledge).

Handler, Richard, and Daniel Segal

1990 Jane Austen and the Fiction of Culture: An Essay on the Narration of Social Realities (Tucson: University of Arizona Press).

Hart, F. Elizabeth

1998 "Matter, System, and Early Modern Studies: Outlines for a Materialist Linguistics," Configurations 6(3): 311-43.

Hartley, David

1967 [1749] Observations on Man, His Frame, His Duty, and His Expectations, 2 vols. (Hildesheim: Georg Olms).

Hays, Mary

1974 [1796] Memoirs of Emma Courtney, edited by Gina Luria, 2 vols. (New York: Garland).

Hazlitt, William

1930-1934 [1829] "Phrenological Fallacies," in The Complete Works of William Hazlitt, edited by P. P. Howe, 21 vols. (London: Dent). First published in Atlas, July 5 and 12.

Herder, Johann Gottfried von

1966 [180o] Outlines of the Philosophy of the History of Man, translated by T. Churchill (New York: Bergman).

Home, Sir Everard

1814 "Observations on the Functions of the Brain," Philosophical Transactions of the Royal Society of London 104: 469-86.

Johnson, Claudia L.

1988 Jane Austen: Women, Politics, and the Novel (Chicago: University of Chicago Press).

Kagan, Jerome

1994 Galen's Prophecy: Temperament in Human Nature (New York: Basic Books).

Lascelles, Mary

1939 Jane Austen and Her Art (Oxford: Clarendon).

Lawrence, Christopher

1990 "The Power and the Glory: Humphry Davy and Romanticism," in Romanticism and the Sciences, edited by Andrew Cunningham and Nicholas Jardine, 213-27 (Cambridge: Cambridge University Press).

Lawrence, William

1822 Lectures on Physiology, Zoology, and the Natural History of Man, Delivered to the Royal College of Surgeons (London: Benbow). 
Litz, A. Walton

1975 "Persuasion: Forms of Estrangement," in Fane Austen: Bicentenary Essays, edited by John Halperin, 221-32 (Cambridge: Cambridge University Press).

Marshall, John G.

1980 "The New Organology," Behaviorial and Brain Sciences 3: 23-25.

Oppenheim, Janet

1991 "Shattered Nerves": Doctors, Patients, and Depression in Victorian England (New York: Oxford University Press).

Poovey, Mary

1984 The Proper Lady and the Woman Writer: Ideology as Style in the Works of Mary Wollstonecraft, Mary Shelley, and Jane Austen (Chicago: University of Chicago Press).

Propp, Vladimir 1968 Morphology of the Folktale, $2 \mathrm{~d}$ ed., translated by Laurence Scott and Louis A. Wagner, edited by Alan Dundes (Austin: University of Texas Press).

Reed, Edward S.

1997 From Soul to Mind: The Emergence of Psychology from Erasmus Darwin to William fames (New

Haven, GT: Yale University Press).

Review of Sir Everard Home

1815 "Observations on the Functions of the Brain," Edinburgh Review 24(48): 439-52.

Richardson, Alan

1994 Literature, Education, and Romanticism: Reading as Social Practice, 1780-1832 (Cambridge:

Cambridge University Press).

1999 "Coleridge and the Dream of an Embodied Mind," Romanticism 5: 1-25.

Shelley, Mary

1985 [1826] The Last Man, edited by Brian Aldiss (London: Hogarth Press).

Shields, Carol

1991 "Jane Austen Images of the Body: No Fingers, No Toes," Persuasions 13: 132-37.

Shuttleworth, Sally

1996 Charlotte Brontë and Victorian Psychology (Cambridge: Cambridge University Press).

Sokolsky, Anita

1994 "The Melancholy Persuasion," in Psychoanalytic Literary Criticism, edited by Maud Ellman, 128-42 (London: Longman).

Sweetser, Eve 1990 From Etymology to Pragmatics: Metaphorical and Cultural Aspects of Semantic Structure (Cambridge: Cambridge University Press).

Wiltshire, John

1992 Jane Austen and the Body (Cambridge: Cambridge University Press). 